ACTA AGROBOTANICA

Vol. 61 (2): 49-56

2008

\title{
THE INFLUENCE OF METEOROLOGICAL FACTORS ON THE HAZEL (CORYLUS L.) POLLEN CONCENTRATION IN SOSNOWIEC IN THE YEARS 1997-2007
}

\author{
Katarzyna Dąbrowska-Zapart \\ Faculty of Earth Sciences, University of Silesia \\ Będzińska 60, 41-200 Sosnowiec, Poland \\ e-mail: kdabrow@wnoz.us.edu.pl
}

Received: 29.09.2008

$\mathrm{S} \mathrm{u} \mathrm{m} \mathrm{m} \mathrm{a} \mathrm{r} \mathrm{y}$

An analysis of hazel pollen seasons in Sosnowiec was presented on the basis of data from the years 1997-2007. The research was conducted by means of the volumetric method using a Burkard-type spore trap. The duration of pollen seasons was determined by means of the $98 \%$ method. The research demonstrated statistically significant correlations between the average, maximum and minimum temperature, relative humidity as well as the number of days with sub-zero temperature and the beginning of the hazel pollen season. It was demonstrated that the duration of the pollen season depended on air relative humidity, insolation and precipitation during the season and the annual sum depended on the weather conditions of the year preceding pollen production and also the weather conditions two years earlier. Significant correlations were also found between weather conditions and the daily concentration of pollen grains. The daily concentration decreased when relative humidity was high and increased with high insolation and air temperature.

Key words: Sosnowiec, pollen season, meteorological factors, hazel

\section{INTRODUCTION}

Hazel belongs to a group of early blossoming trees. The moment when hazel blossoms is considered to be the beginning of botanical early spring. In Poland one species grows in the wild, that is, the Common Hazel (Corylus avellana). There are some other species in horticulture. Among arborescent plants, hazel pollen grains, apart from birch and alder, are the most common cause of pollinosis ( $\mathrm{H} \mathrm{o} \mathrm{fm} \mathrm{an} \mathrm{and} \mathrm{M} \mathrm{i} \mathrm{h} \mathrm{a} \mathrm{lik,}$ 1998). It is assumed that the first symptoms of pollinosis appear at a concentration of 35 grains per cubic metre of air (R a p i j k o et al. 2004). Hazel pollen contains strong allergens, but it does not cause severe allergic symptoms, because the pollen concentration in Poland's urbanized areas does not usually exceed medium values (usually 20-30 grains per 1 cubic metre of air). Hazel pollen allergy is often accompanied by hypersensitivity to alder and birch pollen allergens as well as allergic symptoms appear after consumption of hazel nuts.

As hazel blossoms at the end of winter and the beginning of spring, it is exposed to sudden weather changes, especially to large temperature fluctuations. This has an impact on considerable differences in the dates of the beginning of pollen seasons and their duration, the periods of maximum pollen concentrations as well as the maximum values of hazel pollen concentrations and also pollen concentrations of other trees which blossom in early spring (D e t a $\mathrm{d} \mathrm{t}$ and Nolard, 2000; Rapiejko, 2003). According to many authors, air temperature during winter and spring is the most important weather element influencing hazel pollen seasons ( $\mathrm{K}$ a s p r z y k, 1997; G a 1 a n et al. 2000; P u c et al. 2006).

The aim of this study was to demonstrate the impact of meteorological conditions on the dates of the beginning and end of pollen seasons, their duration, annual sums and the daily concentration of hazel pollen grains in Sosnowiec over 11 years.

\section{MATERIALS AND METHODS}

An analysis of the hazel pollen concentration in the air of Sosnowiec was performed on the basis of data from the years 1997-2007. The research was conducted by means of the volumetric method using a Burkard-type spore trap. The trap site was placed at a height of approximately 20 metres above the ground on the premises of the Faculty of Earth Sciences at the University of Silesia in Sosnowiec (50 $10^{\circ} 50^{\prime \prime} \mathrm{N}$ and $19^{\circ} 08^{\prime} 20^{\prime \prime} \mathrm{E}, 262.5$ metres above sea level). 
A microscopic analysis, after slides had been stained with alkaline fuchsin, was performed on the surface of 4 horizontal strips (Mandrioli et al. 1998). The result was expressed as the average daily number of pollen grains per 1 cubic metre of air. The duration of pollen seasons was determined by means of the $98 \%$ method, according to which the beginning of the season is on the day when $1 \%$ of the cumulative sum of a given taxon's pollen is recorded and the end when $99 \%$ of pollen is found (E m b e r lin et al. 1994; S pi e k s ma and Nikkel s, 1998).

In order to assess the impact of meteorological factors on the selected properties of pollen seasons - the beginning of the season, the annual sum of the pollen grain concentration, the duration of the season and the daily concentration - the average monthly and daily values of 7 weather elements were taken into account: average, minimum, maximum and near-ground temperature, precipitation, relative humidity and insolation. The correlations between individual meteorological conditions and various properties of the hazel pollen season were established by means of Pearson correlation coefficients and multiple linear regression (S t a n is z, 2007).

\section{RESULTS}

During the eleven-year period examined, the hazel pollen season started earliest in 2007 (10.01) and latest in the years 2005 (14.03) and 2003 (8.03) (Tab. 1). The beginning of the pollen season in the years examined was influenced by average, minimum and maximum temperature and relative humidity 40 days before the season, which is confirmed by correlation coefficients between meteorological conditions and the date of the beginning of the season (for the average temperature $\mathrm{r}=-0.78$, for the minimum temperature $\mathrm{r}=-0.81$, for the maximum temperature $r=-0.73$, for relative humidity $\mathrm{r}=-0.62$ respectively). High temperatures and high relative humidity caused the examined taxon's pollen to be present earlier in the air in the years 1998, 2000, 2002, 2004 and 2007 (Figs 1-3). The temperatures directly preceding the beginning of the season are also important. In all the years, the hazel pollen season started after a few or between ten and twenty days with the maximum temperature above zero. The year 1998 was an exception - this year, the maximum temperature fell below zero one day before the beginning of the pollen season (Fig. 1).

Table 1

Characteristics of hazel pollen seasons in Sosnowiec.

\begin{tabular}{|c|c|c|c|c|c|c|}
\hline \multirow{2}{*}{ Year } & \multicolumn{2}{|c|}{ Length of pollen season } & \multirow{2}{*}{$\begin{array}{c}\text { Peak } \\
\text { concentration }\end{array}$} & \multirow{2}{*}{$\begin{array}{l}\text { Date of peak } \\
\text { concentration }\end{array}$} & \multirow{2}{*}{ Annual total } & \multirow{2}{*}{$\begin{array}{l}\text { Number of days } \\
\text { with }>35 \text { grains }\end{array}$} \\
\hline & Period & Days & & & & \\
\hline 1997 & 19.02. -6.04 & 46 & 75 & 24.02 & 463 & 6 \\
\hline 1998 & 24.01. -21.03 & 56 & 70 & 21.02 & 329 & 2 \\
\hline 1999 & 8.02. -27.03 & 47 & 304 & 3.03 & 667 & 3 \\
\hline 2000 & 3.02. -3.04 & 60 & 91 & 29.02 & 466 & 5 \\
\hline 2001 & 7.02. -31.03 & 52 & 99 & 12.03 & 875 & 8 \\
\hline 2002 & 2.02. -19.03 & 45 & 86 & 12.02 & 680 & 7 \\
\hline 2003 & 8.03. -3.05 & 56 & 106 & 26.03 & 606 & 5 \\
\hline 2004 & 3.02. -3.04 & 59 & 191 & 18.03 & 833 & 5 \\
\hline 2005 & 14.03. -10.04 & 24 & 135 & 25.03 & 602 & 7 \\
\hline 2006 & 19.02. -27.04 & 67 & 214 & 30.03 & 767 & 6 \\
\hline 2007 & $10.01-18.03$ & 67 & 114 & 6.03 & 947 & 10 \\
\hline
\end{tabular}

Table 2

Correlation coefficients between hazel pollen concentrations and meteorological parameters in the years 1997-2007 (N=591, $<<0,05)$.

\begin{tabular}{ccccccc}
\hline \multicolumn{4}{c}{ Temperature $\left({ }^{\circ} \mathrm{C}\right)$} & \multirow{2}{c}{$\begin{array}{c}\text { Precipitation } \\
(\mathrm{mm})\end{array}$} & Humidity (\%) & Insolation (h) \\
\hline $0.28^{*}$ & $0.20^{*}$ & $0.30^{*}$ & $0.18^{*}$ & -0.08 & $-0.13^{*}$ & $0.12^{*}$ \\
\hline
\end{tabular}

* Correlation statistically significant 

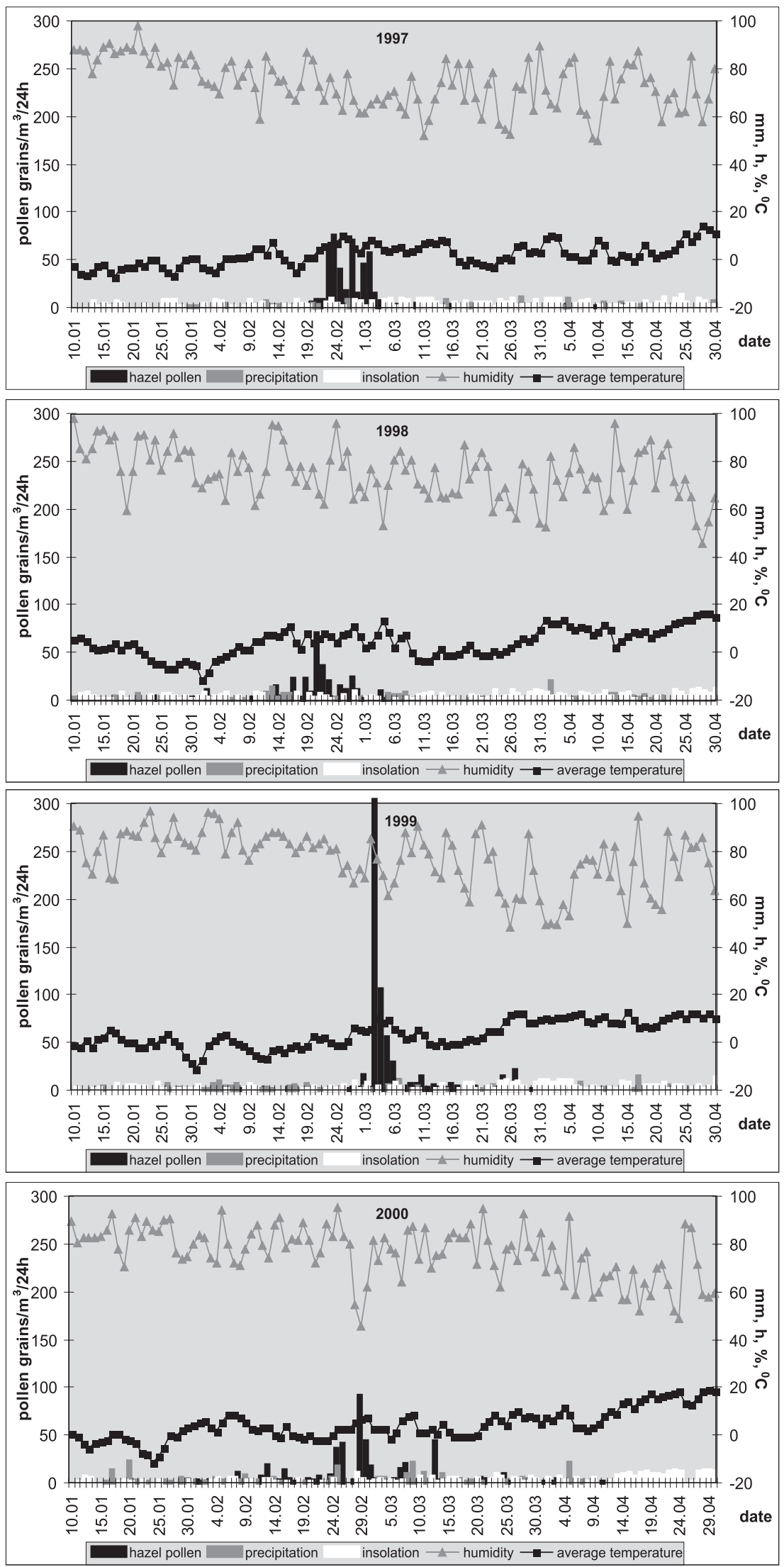

Fig. 1. Correlation among the number of hazel pollen and meteorological factors in the years 1997-2000. 

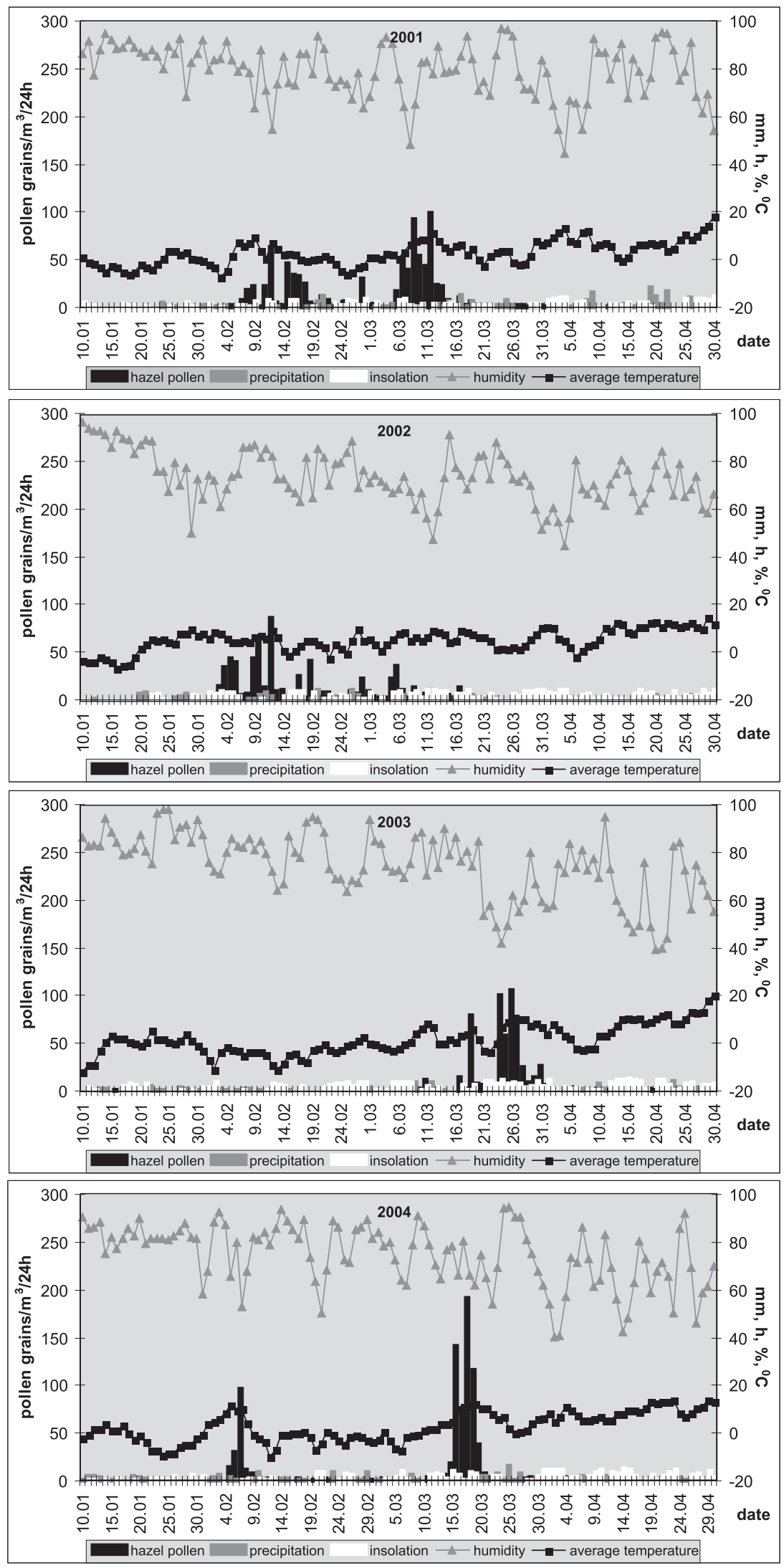

Fig. 2. Correlation among the number of hazel pollen and meteorological factors in the years 2001-2004. 


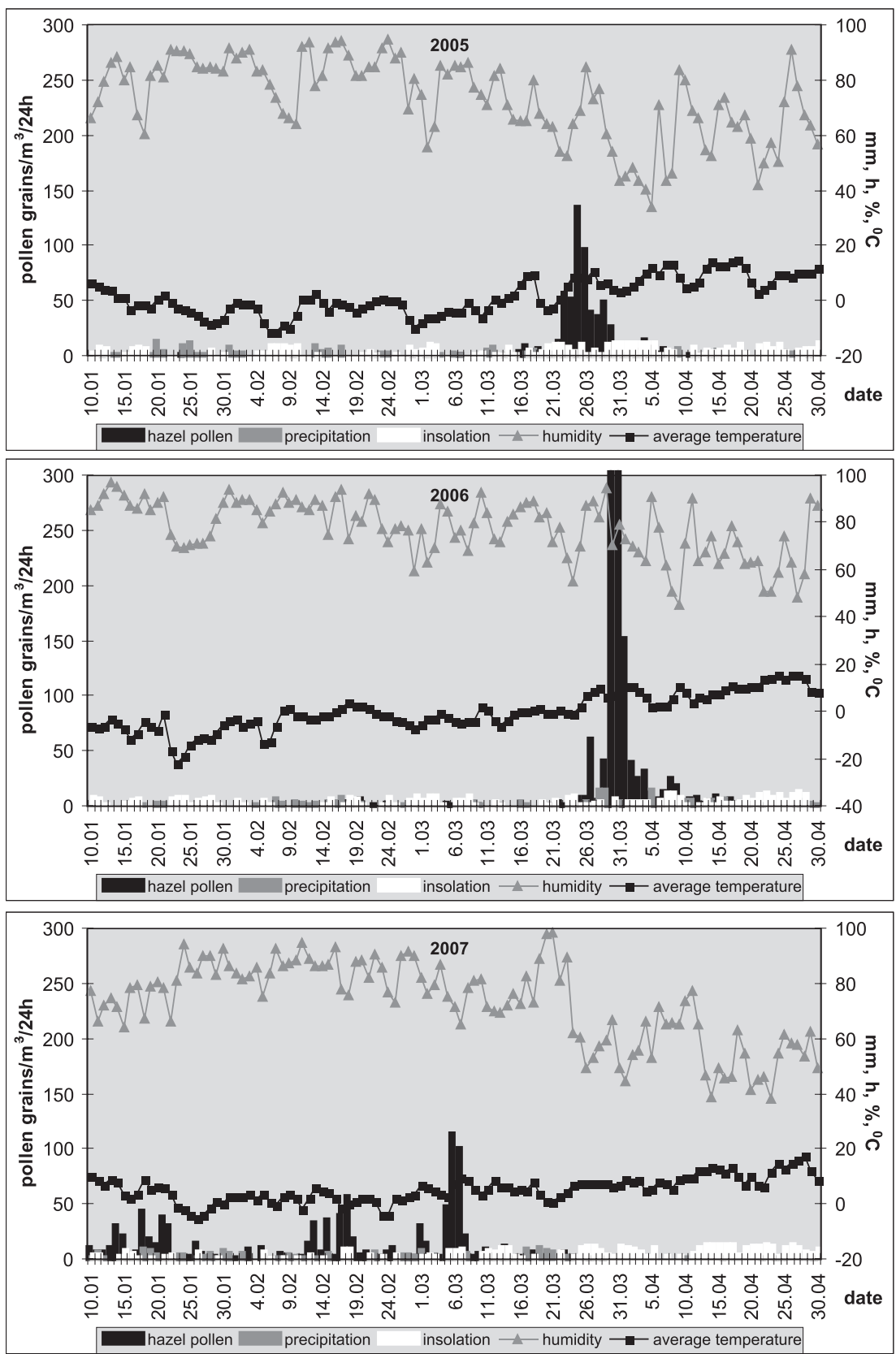

Fig. 3. Correlation among the number of hazel pollen and meteorological factors in the years 2005-2007.

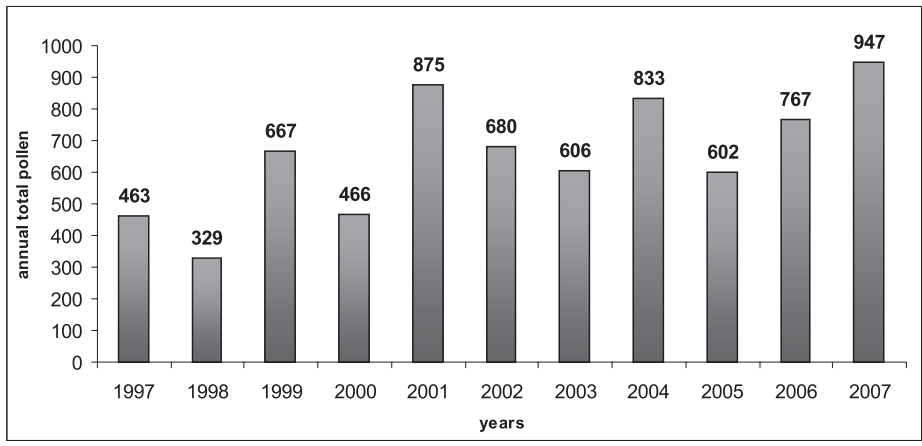

Fig. 4. Annual total hazel pollen in the years 1997-2007. 
The number of days with sub-zero average temperature also influenced the beginning of the hazel pollen season. The greater the number of such days from the beginning of January, the later the pollen season started. In 2005, the number of days with sub-zero temperature amounted to 48 , in 2003 - 46, whereas in 2007 the average temperature remained above zero until 22 January (Fig. 3).

Moreover, the impact of cumulative average temperature calculated from 1 January (over $0^{\circ} \mathrm{C}$ and over $5.5^{\circ} \mathrm{C}$ ) on the date of the beginning of the pollen season was examined, but this method did not give positive results.

The shortest pollen season was in $2005-24$ days, the longest seasons in 2006 and $2007-67$ days. The correlation coefficients between weather elements and the duration of hazel pollen seasons calculated for individual pollen seasons indicate that there is a statistically significant negative correlation between the season duration and the average $(\mathrm{r}=-0.62)$ and maximum $(\mathrm{r}=-0.65)$ daily temperature and insolation $(\mathrm{r}=-0.63)$ during the season. A statistically significant positive correlation was found for relative humidity $(\mathrm{r}=0.73)$ and precipitation $(0.69)$ during the season as well as for precipitation in March (0.65). This indicates that the hazel pollen season is extended when relative humidity and precipitation is high. On the other hand, high temperature and insolation cause pollen of this taxon to be present in the air over a shorter period of time. However, after conducting the $r$ coefficient significance test, that is, after calculating the coefficient of determination $\mathrm{r}^{2}$, it turned out that only a small percentage of the variability in the duration of pollen seasons could be explained by the correlation of this property with the weather elements examined (average temperature $-38 \%$, maximum temperature $-42 \%$, insolation $-40 \%$, relative humidity $-53 \%$, precipitation during the season $-48 \%$, precipitation in March $-42 \%$ ).

A model of the dependence of the pollen season duration on weather conditions developed by means of the multiple linear regression method is as follows:

$$
\begin{gathered}
\mathrm{Y}(\text { duration })=0.835 \mathrm{~T}_{\text {aver }}-1.590 \mathrm{~T}_{\max }+9.164 \\
\text { Humidity }+0.537 \text { Precipitation }+2.067 \text { Insolation } \\
-20.61 \pm 0.052
\end{gathered}
$$

Relative humidity, precipitation and insolation are the statistically significant structural parameters of the model. Because these parameters are positive, they will have an impact on the pollen season extension. The above regression model is characterized by an estimation error of 0.052 and a corrected coefficient of determination $r^{2}$ of 0.91 . Thus, the developed model accounts for approximately $91 \%$ of the variability in the duration of hazel pollen seasons. This indicates that there is a strong linear dependence between weather elements and the duration of the pollen seasons of the taxon in question.

The annual sums of hazel pollen ranged from 947 in 2007 to 329 grains in 1998. In 2001 and 2004, the annual sums were also high and they amounted to 875 and 833 pollen grains, respectively (Fig. 4). An analysis of the impact of the selected meteorological factors on the annual sum revealed the highest positive correlation for the average temperature in May in the preceding year and the highest negative correlation for precipitation in June in the preceding year. A statistically significant correlation with the meteorological conditions two years before the season was also found, that is, with the average and maximum temperature in September. An analysis of the annual sums during individual years did not result in finding two-year periodicity, which means that the years with the high values of annual sums are separated by the years with low annual sums (Fig. 4).

The period of maximum hazel concentrations started in all the study years after the snow cover had totally disappeared. The days with maximum pollen concentrations occurred in the years examined between 2 February and 9 April (Figs 1-3). There were few days with the threshold hazel pollen concentration, that is, one which results in the onset of clinical symptoms in people with hypersensitivity: from 2 days in 1998 to 10 days in 2007 (Tab. 1).

The correlation coefficients between weather elements and the daily concentration indicated that the daily concentration of hazel pollen grains increased together with air temperature and insolation, whereas it decreased when relative humidity was high (Tab. 2). A statistically significant negative correlation with precipitation was not found.

\section{DISCUSSION}

Exposure to hazel pollen allergens varied considerably in the years examined. The differences are visible in the dates of the beginning and duration of pollen seasons, maximum daily concentrations of pollen grains and annual sums. Meteorological conditions have a significant impact on the time of pollen production by plants, especially those which blossom in early spring (K a sprzyk, 1997; Wery s zk o- C h mi e lewska and Rapiejko, 1997). The research conducted confirms that the average, minimum, maximum and near-ground temperature, relative humidity, insolation and precipitation influence some properties of pollen seasons. Similar correlations were found in Poznań (S t a c h , 2000), Spain (J a t o et al. 2002) and Szczecin (P u c, 2007). 
The average, minimum and maximum temperature as well as relative humidity 40 days before the season had an impact on the beginning of the pollen season in the years. Moreover, a significant correlation between the beginning of the hazel season and the number of days with sub-zero temperature from the beginning of the year was found, which was also demonstrated by U r u s k a (2003) in her research conducted in Gdańsk. Many authors (F r e n g u e 11 i et al. 1992; Rodkiewicz et al. 1996; Minero et al. 1999; Garcia-Mozo et al. 2000) emphasize that trees which blossom in early spring start to produce pollen when the cumulative temperature from 1 January reaches a certain threshold specific for every species. However, the research conducted in Sosnowiec did not confirm the effectiveness of this method (the sums of the values of average daily temperatures over $0^{\circ} \mathrm{C}$ and over $5.50^{\circ} \mathrm{C}$ were taken into account).

The duration of the hazel pollen seasons in the years examined ranged from 24 to 67 days. The statistical analysis demonstrated that relative humidity, precipitation and insolation during the pollen season had the most significant impact on this property of the pollen season of the studied taxon. An increase in the above parameters should be accompanied by an extension of the season. Additionally, grains which are transported from distant places can have an impact on the extension of the hazel pollen season $(\mathrm{H} \mathrm{j} \mathrm{e} 1 \mathrm{~m} \mathrm{roos}$, 1992; P u c , 2006).

A great deal of research proves that the annual sum of pollen grains of some tree species is dependent on the weather elements of the year preceding the season or even two years earlier (S a r va s, 1972; Rodkiewicz et al. 1996; Norris-Hi11, 1998). In Sosnowiec the average temperature in May and precipitation in June in the year preceding the season had an impact on the annual sum of hazel pollen. A statistically significant correlation with the average and maximum temperature in September two years earlier was also found. An analysis of the annual sums in individual years resulted in finding that there was no twoyear periodicity, that is the years with high and low values did not occur alternately. Furthermore, it was found that there was a slight tendency for the annual sums of hazel pollen grains to increase, but they did not exceed 1000 grains in all the years examined. The relatively low values of annual sums, in spite of the large production of pollen by the inflorescence, might be caused by light frosts, which frequently occur during the flowering of hazel (D yak ow ska, 1937; P i otrows ka - Wery s zko, 2001).

The hazel pollen season can be classified as a compact one (Hy d e , 1956). The number of pollen grains in the air increased, reached one distinct maximum and then decreased. The years 2001, 2004 and
2007 were an exception - more than one maximum was then found (Figs 1-3).

\section{CONCLUSIONS}

1. The average, minimum and maximum temperature as well as relative humidity 40 days before the season and the number of days with sub-zero temperature had an impact on the beginning of the hazel pollen season.

2. The average temperature in May and precipitation in June in the preceding year as well as thermal conditions in September two years before the season influenced the annual sums of hazel pollen.

3. The duration of the pollen season depended on air relative humidity, insolation and precipitation during the season.

4. The daily concentration of hazel pollen grains increased when the air temperature and insolation were high and fell with an increase in air relative humidity.

\section{Acknowledgments}

This research has been financed by KBN Grant No. PB-P-04-003-00-08 (years 2008 - 2010).

\section{REFERENCES}

Detandt M., Nolard N., 2000. The fluctuation of the allergenic pollen content of the allergenic pollen content of the air in Brussels (1982 to 1997). Aerobiologia, 16: 55-61.

Dyakowska J., 1937. Researches on the rapidity of the falling down of pollen of some trees. Bull. De I'Acad. Polon. Des. Sc. Et des Letters. Ser. B, Classe des Sc. Mathem. et Nat.: 155-168.

Emberlin J., Jones S., Bailey J., Cault on E., Corden J., Dubbels S., Evans J., Mc Donagh N., Millington W., Mullins J., Russel R., Spencer T., 1994. Variation in the start of the grass pollen season at selected sites in the United Kingdom 1987-1992. Grana, 33: 94-99.

Frenguelli G., Bricchi E., Romano B., Mincigrucci G., Ferranti F., Antognozzi E., 1992. The role of fair temperature in determining dormancy release and flowering of Corylus avellana L. Aerobiologia, 8: 415418.

Galan C., Alcazar P., Carninano z P., Garcia H., Dominiguez-Vilches E., 2000. Meteorogical factors affecting daily Urticaceae pollen counts in southwest Spain. Int. J. Biometeorol. 43: 191-195.

Garcia-Mozo H., Galán C., Gomez-Casero M., T., Dominiguez-Vilches E., H., 2000. A comparative study of different temperature accumulation methods for predicting the start of the Quercus pollen season in Córdoba (South West Spain). Grana, 39:194-199. 
Hjelmroos M., 1992. Long - distance transport of Betula pollen grains and allergic symptoms. Aerobiologia, 8: $231-236$.

Hofman T., Michalik J., 1998. Alergia pyłkowa/Pollen allergy. TotalDruk, Poznań

Hyde H., 1956. Tree pollen in Great Britain. Acta Allerg. 10: 224-245.

Jato V., Dopazo A., Jesú s-Aira M., 2002. Influence of precipitation and temperature on airborne pollen concentration in Santiago de Compostela (Spain). Grana, 41: 232-241.

Kasprzyk I., 1997. Analiza porównawcza opadu pyłku w 3 punktach w środkowej Polsce/Comparative analysis of pollen fall at 3 sites in central Poland. Mat. I Ogólnop. Konf. Nauk. Biologia kwitnienia, nektarowania i zapylania roślin, Lublin: 210-214.

Mandrioli P., Comtois P., Dominguez-Vilches E., Galan Soldevilla C., Syzdek L., Isard S., 1998. Sampling: principles and techniques. [In:] Methods in aerobiology. (Red.) P. Mandrioli, P. Comtois, V. Levizzani, Pitagora Editrice Bologna: 47-112.

Minero G. F. J., Morales J., Tomas C., Can dau P., 1999. Relationship between air temperature and the start of pollen season emission in some arboreal taxa in Southwestern Spain. Grana, 38: 306-310.

Norris-Hill J., 1998. A method to forecast the start of the Betula, Platanus and Quercus pollen seasons in Northon London. Aerobiologia, 14: 165-170.

Piotrowska-Weryszko K., 2001. Analiza zawartości ziarn pyłku w aeroplanktonie Lublina w latach 1995-1999/ The analysis of pollen content in aeroplankton of Lublin in the years 1995-1999. Praca doktorska, Archiwum Katedry Botaniki Akademii Rolniczej w Lublinie: 191.

Puc M., 2006. Ragweed and mugwort pollen in Szczecin, Poland. Aerobiologia, 22: 67-78.

Puc M., 2007. The effect of meteorological conditions on hazel (Corylus spp.) and alder (Alnus spp.) pollen concentration in the air of Szczecin. Acta Agrobot. 60 (2): 65-70.

Puc M., Weryszko-Chmielewska E., Piotrowska K., Grinn-Gofroń A., Myszkowska D., Rapiejko P., Antonik P., Malkiewicz M., Puc M., 2006. Stężenie pyłku olszy w powietrzu wybranych miast Polski w $2006 \mathrm{roku} /$ The alder pollen concentration in the air of selected Polish cities in 2006. Alergoprofil, 2 (2): 36-41.

Rapiejko P., 2003. Medycyna a Palinologia/Medicine and palinology. [In:]: Palinologia Dybova-Jachowicz S., Sadowiska A. (red.). Kraków, Inst. Botaniki PAN: 63-68.

Rapiejko P., Lipiec A., Wojdas A., Jurkiewicz D., 2004. Threshold pollen concentration necessary to evoke allergic symptoms. Int. Rev. Allergol. Clin. 10 (3): 91-94.

Rodkiewicz B., Śnieżko R., Fryk B., Niewęgłowska B., Tchórzowska D., 1996. Embriologia Angiospermae Rozwojowa i Eksperymentalna/Developmental and Experimental Angiospermae Embryology. Wyd. UMCS, Lublin.
Sarvas R., 1972. Investigation on the annual cycle of development of forest trees. Active period. Comm. Inst. Fenn. 73: 3 .

Spieksma F. Th. M., Nikkels A. H., 1998. Airborne grass pollen in Leiden, The Netherlands:annual variations and trends in quantities and season starts over 26 years. Aerobiologia, 14:347-358.

Stach A., 2000. Variation In pollen concentration of the most allergenic taxa in Poznań (Poland), 1995-1996. Aerobiologia, 16: 63-68.

Stanisz A., 2007. Przystępny kurs statystyki. StatSoft Polska, Kraków, 2: 21-143.

Uruska A., 2003. Wpływ wybranych czynników meteorologicznych na zmianę koncentracji ziarn pyłku drzew w atmosferze Gdańska/The influence of selected meteorological factors on variation of tree pollen concentrations in the air in Gdańsk. Ann. Univ. Mariae CurieSkłodowska, Sect. Hortic. EEE XIII: 293-301.

Weryszko-Chmielewska E., Rapiejko P., 1997. Porównanie opadu pyłkowego kilku alergogennych taksonów Lublinie w latach 1996-1997 / A comparison of pollen deposition of several allergenic taxa in Lublin in the years 1996-1997. Mat. I Ogólnopolskiej Konf. Nauk. „Biologia kwitnienia, nektarowania i zapylania roślin”, Lublin: 232-236.

\section{Wpływ warunków meteorologicznych na stężenie pyłku leszczyny (Corylus L.) w Sosnowcu w latach 1997-2007}

\section{Streszczenie}

Analizę sezonów pyłkowych leszczyny w Sosnowcu przedstawiono na podstawie danych z lat 1997 -2007 . Badania prowadzono metodą wolumetryczną aparatem typu Burkard. Długość sezonów pyłkowych wyznaczono metodą 98\%. Badania wykazały statystycznie istotne korelacje pomiędzy temperaturą średnią, maksymalną i minimalną, wilgotnością względną oraz liczbą dni z temperaturą poniżej zera a początkiem sezonu pyłkowego leszczyny. Wykazano, że długość sezonu pyłkowego zależała od wilgotności względnej powietrza, usłonecznienia i opadu atmosferycznego w sezonie zaś suma roczna od warunków pogodowych roku i dwóch lat poprzedzających pylenie. Znaleziono również istotne korelacje pomiędzy warunkami pogodowymi a stężeniem dobowym ziarn pyłku. Stężenie dobowe malało, kiedy wilgotność względna była wysoka a wzrastało przy wysokim usłonecznieniu i temperaturze powietrza. 